\title{
Izbira stanovanjske lokacije ter vloga mobilnosti, družbenogospodarskih dejavnikov in namenske rabe prostora $v$ pakistanskem mestu Hafizabad
}

Izbira stanovanjske lokacije v državah v razvoju in njena povezava $\mathrm{z}$ mestnim prevozom sta slabo raziskani in ne povsem dobro razumljeni, vrzel v poznavanju razmer pa je še večja v primeru malih mest $\mathrm{v}$ teh državah. Avtorji v članku proučujejo pakistansko mesto Hafizabad, pri čemer je njihov cilj zagotoviti podatke za prihodnje kvantitativne analize, ki bodo zajele izbire stanovanjskih lokacij v malih mestih na indijski podcelini. Avtorji so anketirali 365 prebivalcev štirih sosesk v mestu, v katerih živi skupno 19.042 ljudi. Anketi se je odzvalo 1,92 \% posameznikov in $12,65 \%$ gospodinjstev, pri čemer je bila stopnja zaupanja pri odgovorih prvih $\pm 5,08 \%$, pri drugih pa $\pm 4,79 \%$. Izsledki kažejo, da sta razpoložljivost komunalne infrastrukture ali storitev ter dostopna cena najpomembnejša dejavnika, ki vplivata na odločitve prebival- cev, da se preselijo. Takoj za njima so dejavniki, povezani $s$ prevozom, dostopnostjo in družbenimi vprašanji, kot je bližina službe in sorodnikov. Vloga prevoza pri izbiri stanovanjske lokacije je v Hafizabadu manj pomembna kot v državah z visokimi dohodki. Ta ugotovitev kaže, kako lahko oblika mest vpliva na potovalne navade prebivalcev in da so manjša mesta bolj strnjena in hodljiva, saj približno 40 \% ljudi v službo hodi peš. Ugotovitve raziskave lahko pristojnim vladnim organizacijam pomagajo učinkovito oblikovati politiko za mala mesta, saj politika, ki se uporablja v velemestih, zanje morda ni najprimernejša.

Ključne besede: izbira stanovanjske lokacije, mestni prevoz, mnenja ljudi, Pakistan 


\section{Uvod}

V zadnjih dveh desetletjih je izbira stanovanjske lokacije pritegnila pozornost raziskovalcev mestnega prevoza, ki proučujejo povezave med mestnimi potovalnimi navadami in namensko rabo prostora. Zanima jih, ali se ljudje odločijo za prebivanje v izbrani soseski, ker se lahko od tam vsak dan lažje vozijo na delo ali lažje dostopajo do neslužbenih destinacij, ali pa lokacijo stanovanja izberejo zaradi drugih dejavnikov, kot so potrebe, povezane z mobilnostjo, vplivi grajenega okolja, njihovi pogledi in življenjski slog ter družbenogospodarski dejavniki.

Po podatkih vlade Islamske republike Pakistan (Government of Pakistan, 2017) je število prebivalcev v državi od leta 1998 do leta 2017 povečalo s 132,4 milijona na 207,8 milijona (57-odstotna rast), kar pomeni, da je med letoma 1998 in 2017, ko sta bila opravljena popisa prebivalstva, letna povprečna stopnja rasti znašala 2,40. Čeprav se je letna rast v primerjavi z obdobjem med popisoma v letih 1981 in 1998 zmanjšala, se je delež mestnega prebivalstva povečal z 32,5 \% (1998) na $36,4 \%$ (2017). To kaže na vse močnejšo urbanizacijo in zgoščanje prebivalstva v mestnih središčih. Mestni stanovanjski fond je pod čedalje večjim pritiskom, kar povzroča nenačrtno širjenje mestnega prostora. Nenadzorovana urbanizacija zato postaja velik izziv za lokalne pakistanske načrtovalske agencije (Ahmad in Anjum, 2012), ki so pripravile že številne razvojne načrte, da bi obvladale nastali položaj, vendar ti načrti postavljenih ciljev niso dosegli. Hameed in Nadeem (2008) sta kritično analizirala procese oblikovanja glavnih mestnih načrtov v Pakistanu in našla več razlogov za njihovo neuspešno izvajanje. Med glavnimi razlogi so bili preveliko zanašanje na sekundarne podatke, premalo zbranih primarnih podatkov in nezadostno sodelovanje javnosti. Posledično mnogi glavni načrti, ki se nanašajo na stanovanjski sektor (npr. določanje prihodnjih območij stanovanjske rasti), ne zadovoljujejo želja in potreb ljudi ter $s$ tem ovirajo uspešno izvajanje razvojnih načrtov.

Razen osnovnih kvantitativnih stanovanjskih kazalnikov podatki iz popisov prebivalstva ne dajejo vpogleda $\mathrm{v}$ odločitve in preference ljudi pri izbiri lokacije doma. Poleg tega ni na voljo dovolj podatkov za proučevanje vloge prevoza in drugih $s$ tem povezanih dejavnikov pri izbiri stanovanjske lokacije $\mathrm{v}$ Pakistanu (in drugih državah na globalnem jugu). V številnih prejšnjih raziskavah te problematike so avtorji ugotovili povezavo med grajenim okoljem in potovalnimi navadami mestnih prebivalcev, slabše pa je raziskan vpliv izbire stanovanja na povezavo med rabo prostora in prevozom (Cao idr., 2009). Glede na to, da je malo raziskovalnih izsledkov, ki bi se nanašali na Pakistan in druge države v razvoju, so primarni podatki še toliko nujnejši in na podlagi tega bi bilo treba zbrati primarne podatke o tej temi tudi za države v razvoju.
Cilj raziskave, navedene v tem članku, je bil zagotoviti zanesljive primarne podatke, na podlagi katerih bi lahko izvedli empirične analize, ki bi zajele izbire stanovanj v malih pakistanskih mestih. Omeniti je treba, da glede na splošno hipotezo raziskave mnenja in navade ljudi v malem pakistanskem mestu niso primerljivi $s$ tistimi v podobno velikih mestih v Severni Ameriki, Evropi, Avstraliji itd. Odločilni razlog za razlike v vedenju ali navadah ljudi je kontekst, ne velikost. Kljub temu lahko v okviru pakistanskega ali južnoazijskega konteksta velikost mesta vpliva na vedenjska neskladja, ki so zaradi razlik $\mathrm{v}$ družbenogospodarskih razmerah in življenjskem slogu med velikimi in srednje velikimi mesti ter malimi mesti lahko precejšnja. Neskladja med različno velikimi mesti so $\mathrm{v}$ državah $\mathrm{v}$ razvoju lahko večja kot $\mathrm{v}$ državah $\mathrm{z}$ visokimi prihodki (to je treba preveriti in bi bila lahko hipoteza drugih raziskav). $\mathrm{V}$ raziskavi, navedeni v tem članku, avtorji obravnavajo pomanjkanje primarnih podatkov, primernih za proučevanje izbire stanovanjskih lokacij ne samo v malih, ampak tudi večjih pakistanskih mestih.

Avtorji so najprej orisali proučevani problem in raziskovalne cilje, nato pa so navedli prejšnje raziskave podobne problematike, opravljene na različnih območjih (večinoma $\mathrm{v}$ razvitih državah ter na Bližnjem vzhodu, v Severni Afriki in na indijski podcelini). $V$ nadaljevanju so navedli raziskovalna vprašanja in hipotezo, značilnosti raziskovalnega območja, raziskovalne spremenljivke ter metode zbiranja in analize podatkov. Vsebina zajema še izsledke, izvedene na podlagi zbranih podatkov, ki se nanašajo na dva širša niza kategoričnih in zveznih spremenljivk, članek pa so sklenili z razpravo in sklepi raziskave.

\section{Prejšnje raziskave}

Izbira stanovanjske lokacije je del človekove samoizbire, pri čemer se ljudje navadno odločajo o tem, kje in kako bodo živeli, kam in kako bodo potovali ipd., na podlagi svojih potreb, preferenc in pogledov. Do zdaj je bila obravnavana v empiričnih raziskavah, ki so temeljile na primarnih podatkih, zbranih v raznih državah, kot so Nizozemska (Van der Vlist idr, 2002; Zondag in Pieters, 2005; Ettema in Nieuwenhuis, 2017), Nemčija (Heldt idr., 2016), Združeno kraljestvo (Kim idr., 2005), ZDA (Schwanen in Mokhtarian, 2004; Bayoh idr., 2006; Waddell idr., 2007; Cao idr., 2010; Pinjari idr., 2011; Sener idr., 2011; Wang idr., 2011; Patacchini in Arduini, 2016), Kanada (Fatmi idr., 2017), Japonska (Ge in Hokao, 2006; Zhang idr., 2014; Yu idr., 2017), Irska (Vega in Reynolds-Feighan, 2009; Humphreys in Ahern, 2017), Italija (Chiarazzo idr., 2014), Francija (Palma idr., 2005; Buczkowska in Lapparent, 2014), Danska (Næss, 2009) in Belgija (van Acker idr., 2014; Vos in Witlox, 2016). Raziskave so vključevale vse od pregledov literature (Van der Vlist idr., 2002), številskih analiz na pod- 
Preglednica 1: Metode, uporabljene v podobnih predhodno izvedenih raziskavah (vir: avtorji)

\begin{tabular}{|c|c|c|c|c|c|}
\hline Raziskava & Velikost vzorca & Stopnja odziva & Proučevano območje & Delež odziva & $\begin{array}{l}\text { Metoda zbiranja } \\
\text { podatkov }\end{array}$ \\
\hline Ahmad, 1992 & $\begin{array}{l}6.275 \text { gospodinjstev, izbranih } \\
\text { s kvazinaključnim } \\
\text { vzorčenjem. }\end{array}$ & - & $\begin{array}{l}26 \text { območij v Karačiju, dolo- } \\
\text { čenih na podlagi družbeno- } \\
\text { gospodarskih značilnosti in } \\
\text { značilnosti sosesk. }\end{array}$ & Ni podatka. & $\begin{array}{l}\text { Anketa o družbenogo- } \\
\text { spodarskih razmerah, } \\
\text { opravljena med leto- } \\
\text { ma } 1987 \text { in } 1988 \text { po } \\
\text { celotnem mestu. }\end{array}$ \\
\hline Ahmad, 1993 & $\begin{array}{l}6.275 \text { gospodinjstev, izbranih } \\
\text { s kvazinaključnim } \\
\text { vzorčenjem. }\end{array}$ & - & $\begin{array}{l}26 \text { območij v Karačiju, dolo- } \\
\text { čenih na podlagi družbeno- } \\
\text { gospodarskih značilnosti in } \\
\text { značilnosti sosesk. }\end{array}$ & $0,38 \%$ (mesto) & $\begin{array}{l}\text { Anketa o družbenogo- } \\
\text { spodarskih razmerah, } \\
\text { opravljena med leto- } \\
\text { ma } 1987 \text { in } 1988 \text { po } \\
\text { celotnem mestu. }\end{array}$ \\
\hline Cao idr., 2006a & $\begin{array}{l}6.000 \text { naključno izbranih } \\
\text { gospodinjstev. }\end{array}$ & $22,8 \%$ (1.368) & $\begin{array}{l}\text { Šest sosesk srednjega dohod- } \\
\text { kovnega razreda v Austinu } \\
\text { v Teksasu, zgrajenih v treh } \\
\text { obdobjih. }\end{array}$ & $4,64 \%$ & $\begin{array}{l}\text { Anketa, poslana po } \\
\text { pošti leta } 1995 .\end{array}$ \\
\hline Cao idr., 2006b & $\begin{array}{l}8.000 \text { ( } 6.746 \text { veljavnih) so- } \\
\text { sesk, naključno izbranih iz } \\
\text { poslovne podatkovne baze. }\end{array}$ & $24,9 \%(1.682)$ & $\begin{array}{l}\text { Osem sosesk z različnimi zna- } \\
\text { čilnostmi, zgrajenih v severni } \\
\text { Kaliforniji v dveh obdobjih. }\end{array}$ & $1,74 \%$ & $\begin{array}{l}\text { Dva kroga anket, } \\
\text { poslanih po pošti } \\
\text { leta } 2003 .\end{array}$ \\
\hline Frank idr., 2007 & $\begin{array}{l}\text { Dva podvzorca: } 2.088 \text { ( } 2.056 \\
\text { veljavnih) in } 1.466 \text { (1.455 } \\
\text { veljavnih) gospodinjstev, } \\
\text { izbranih iz podatkovne } \\
\text { zbirke projekta SMARTRAQ. }\end{array}$ & $30,4 \%$ & $\begin{array}{l}\text { Atlantsko metropolitansko } \\
\text { območje, sestavljeno } \\
\text { iz } 13 \text { okrožij. }\end{array}$ & Ni podatka. & $\begin{array}{l}\text { Računalniško podprta } \\
\text { telefonska anketa, } \\
\text { opravljena leta } 2001 \\
\text { in } 2002 .\end{array}$ \\
\hline $\begin{array}{l}\text { Handy in } \\
\text { Clifton, } 2001\end{array}$ & $\begin{array}{l}6.000 \text { anketirancev } \\
\text { in } 75 \text { intervjuvancev }\end{array}$ & $22,8 \%$ (1.368) & $\begin{array}{l}\text { Šest sosesk srednjega dohod- } \\
\text { kovnega razreda v Austinu } \\
\text { v Teksasu, zgrajenih v treh } \\
\text { obdobjih. }\end{array}$ & $4,64 \%$ & $\begin{array}{l}\text { Anketa, poslana po } \\
\text { pošti leta 1995, in } \\
\text { fokusna skupina, } \\
\text { oblikovana leta } 1997 .\end{array}$ \\
\hline Ibrahim, 2017 & 224 gospodinjstev & - & $\begin{array}{l}\text { Sedem stanovanjskih sosesk v } \\
\text { Alexandriji }\end{array}$ & $0,01 \%$ (mesto) & Terenska anketa \\
\hline $\begin{array}{l}\text { Kitamura idr., } \\
1997\end{array}$ & $\begin{array}{l}5.472 \text { naključno izbranih } \\
\text { gospodinjstev }\end{array}$ & $17,6 \%(963)$ & $\begin{array}{l}\text { Pet raziskovalnih območij } \\
\text { v približni velikosti kvadratne } \\
\text { milje v predelu San Francisco } \\
\text { Bay }\end{array}$ & Ni podatka. & $\begin{array}{l}\text { Anketa, poslana po } \\
\text { pošti. }\end{array}$ \\
\hline Painter, 1996 & $\begin{array}{l}496 \text { naključno izbranih } \\
\text { pešcev }\end{array}$ & - & $\begin{array}{l}\text { Tri podobne ulice in pešpot } v \\
\text { Londonu }\end{array}$ & Ni podatka. & $\begin{array}{l}\text { Ulična anketa, opra- } \\
\text { vljena leta } 1992 .\end{array}$ \\
\hline $\begin{array}{l}\text { Mokhtarian, } \\
2003\end{array}$ & 8.000 gospodinjstev & $\begin{array}{l}25,0 \% \text { (2.000: } \\
1.358 \text { upošte- } \\
\text { vanih } \\
\text { zaposlenih) }\end{array}$ & $\begin{array}{l}\text { Tri soseske na območju San } \\
\text { Francisco Bay }\end{array}$ & Ni podatka. & $\begin{array}{l}\text { Anketa, poslana po } \\
\text { pošti. }\end{array}$ \\
\hline
\end{tabular}

lagi podatkovnih zbirk popisov na državni (Zondag in Pieters, 2005) in mestni ali regionalni ravni (Wang idr., 2011; Vega in Reynolds-Feighan, 2009; Cao idr., 2010; Pinjari idr., 2011; Sener idr., 2011; Buczkowska in Lapparent, 2014; Heldt idr., 2016) in matematičnega modeliranja na podlagi primarnih podatkov (Schwanen in Mokhtarian, 2004; Kim idr., 2005; Bayoh idr., 2006; Ge in Hokao, 2006; Næss, 2009; Chiarazzo idr., 2014; van Acker idr., 2014; Zhang idr., 2014; Patacchini in Arduini, 2016; Vos in Witlox, 2016; Fatmi idr., 2017; Humphreys in Ahern, 2017; Yu idr., 2017) do statističnih analiz na podlagi podatkov, pridobljenih s simulacijo (Palma idr., 2005). Večina raziskav je bila opravljena na podlagi matematičnega modeliranja primarnih podatkov. Geografsko je bila večina raziskovalnih območij v ZDA, nekatere raziskave pa so obravnavale tudi države v razvoju, kot so Kitajska (Biying idr., 2012; Næss, 2013; Wu idr., 2013; Yang idr., 2013; Wang idr., 2016; Zhuge idr., 2016; Wang idr., 2018), Južna Koreja (Jun idr., 2013; Yi in Lee, 2014; Park in Kim, 2016), Tajska (Choocharukul idr., 2008), Vietnam (Tran idr., 2016), Čile (Balbontin idr., 2015) in Izrael (Frenkel idr., 2013).

Delež opravljenih raziskav, ki so zajemale izbire stanovanjskih lokacij na indijski podcelini, Bližnjem vzhodu in v Severni Afriki je zelo majhen. Razen nekaterih omembe vrednih izjem, kot so študije, izvedene v Indiji (Schwanen in Mokhtarian, 2003; Molugaram in Rao, 2005; Srinivasan, 2005; Lall idr., 
2006), Bangladešu (Choudhury in Ayaz, 2015), Iranu (Masoumi, 2013) in Egiptu (Ibrahim, 2017), je le malo raziskav poskušalo približati jasno sliko glede izbire lokacij stanovanj v tem delu sveta. Raziskav, ki bi se nanašale na Pakistan, skoraj ni. Zaradi pogostejšega proučevanja tovrstnih izbir v Indiji lahko izsledke indijskih raziskav posplošimo še za Pakistan, vendar bi bilo treba zaradi nekaterih ključnih razlik (večinoma povezanih z verskimi prepričanji) za Pakistan izvesti ločene študije. Izsledke ene izmed redkih raziskav, ki se nanašajo na Pakistan, je leta 1992 objavila Nuzhat Ahmad (Ahmad, 1992), ki je na podlagi podatkov ankete o družbenogospodarskih razmerah, opravljene v Karačiju med letoma 1987 in 1988, proučevala 6.275 gospodinjstev v navedenem mestu. Na podlagi analize teh podatkov je ugotovila, da je za določanje lokacijskih izbir in mobilnosti gospodinjstev pomembna etnična pripadnost družin. Poleg tega je ugotovila povezavo med navedenim ter nenačrrnima širjenjem in rastjo Karačija. Še eno raziskavo je izvedla Kerry M. Connor (1989) in ugotovila je, da etnografske vezi in vpletenost politike vplivajo na odločitve, povezane z izbiro lokacije stanovanja. Ti študiji, ki spadata med redke raziskave o Pakistanu, sta bili opravljeni že pred mnogimi leti in se le slabo ali se sploh ne navezujeta na potovalne navade mestnih prebivalcev.

Pregled preteklih raziskav kaže, da je bila ta tema proučevana predvsem $s$ kvantitativnimi metodami in verjetnostnim vzorčenjem kot glavno metodo vzorčenja in pridobivanja anketirancev. V mnogih tovrstnih raziskavah so bili za določitev ciljne populacije in velikosti vzorca uporabljeni tudi vzorci, ki so že bili uporabljeni drugje (npr. v popisih prebivalstva, prejšnjih raziskavah in raznih podatkovnih zbirkah). Stanovanjske soseske so bile uporabljene kot glavna enota analize na različnih območjih. Glavni razlog za izbiro teh sosesk so bili podobnosti ali razlike v družbenogospodarskih značilnostih in obdobje, $\mathrm{v}$ katerem so bile te soseske zgrajene in naseljene. Uporabljena sta bila dva glavna pristopa $\mathrm{k}$ zbiranju podatkov: neposredno anketiranje na terenu in ankete, poslane po pošti. Omejitev, povezana $\mathrm{z}$ anketami, poslanimi po pošti, je nizka stopnja odziva, kar je razvidno tudi iz pregleda tovrstnih raziskav, saj v nobeni ni bila dosežena stopnja, višja od $33 \%$ (glej preglednico 1). Delež odziva (delež anketirancev v celotnem številu prebivalcev soseske ali mesta) pa je bil med $1,74 \%$ in $4,64 \%$. V preglednici 1 so povzeti izsledki nekaterih predhodnih raziskav.

\section{Metodologija}

V raziskavi, navedeni v tem članku, avtorji predpostavljajo, da je izbira stanovanja odvisna od konteksta, tj. da se ljudje v Pakistanu drugače odločajo, kjer bodo živeli, kot v drugih državah. Razlike v odločanju so večinoma povezane $s$ kulturnimi vprašanji (vero, lokalnim življenjem in miselnostjo), družbenogospodarskimi razmerami (različni načini služenja denarja), družbenimi razredi in povezanostjo $s$ prostorom ter geografskimi značilnostmi (podnebjem). Ti dejavniki lahko vplivajo na drugačne pristope $\mathrm{k}$ izbiri stanovanjskih lokacij $\mathrm{v}$ malih mestih v Pakistanu kot v razvitih državah ali državah z visokimi dohodki. Domneva temelji na hipotezi, da so povezave med mestnim prostorom in mestnimi potovalnimi navadami ( $v$ tem primeru vsakodnevno vožnjo v službo ali šolo) močno odvisne od konteksta, zato oblikovanje politike mestne mobilnosti ne more temeljiti na raziskavah ali konceptih, ki se izvajajo in uporabljajo v državah z visokimi dohodki, ampak na lokalnih raziskavah. $V$ raziskavi so navedeni podatki, ki dajejo osnovo poglobljenim analizam $\mathrm{v}$ prihodnjih raziskavah. Glavno vprašanje je, kako Pakistanci v malih mestih izbirajo lokacijo svojega stanovanja.

\subsection{Proučevana območja}

Življenje v velikih mestnih središčih je skupek najrazličnejših procesov, zaradi katerih je iz empiričnih raziskav, opravljenih na urbanih območjih, zelo težko izluščiti zanesljive izsledke. Izvajanje empiričnih raziskav v velikih mestnih središčih zahteva veliko napora in sredstev, da se zagotovijo zanesljive ugotovitve. Po drugi strani mala mesta omogočajo zanesljive analize manj kompleksnega mestnega življenja na podlagi oblikovanega raziskovalnega okvira. Številne osnovne dejavnike je tako lažje proučevati kot $\mathrm{v}$ velikih mestnih središčih. Na podlagi opisanega je bilo za raziskavo izbrano mestece Hafizabad v osrednjem delu pakistanske regije Pundžab, v katerem je leta 2017 živelo 245.784 prebivalcev (glej sliko 1). Na podlagi zadnjega popisa prebivalstva (Government of Pakistan, 2017) je v Hafizabadu 37.270 stanovanjskih enot, posamezno gospodinjstvo pa v povprečju obsega 6,6 osebe, kar je skoraj enako državnemu povprečju, ki znaša 6,5 osebe.

Najbližje večje mesto je Gudžranvala (število njegovih prebivalcev je leta 2017 znašalo 2,03 milijona), ki je $55 \mathrm{~km}$ proti vzhodu. Hafizabad je z njim močno povezan in med mestoma poteka dnevna migracija, čeprav samo $\mathrm{v}$ omejenem obsegu. Istoimensko okrožje Hafizabad je znano po pridelavi riža in bombaža, mesto Hafizabad kot njegov sedež pa ponuja zaposlitvene možnosti tudi okoliškim prebivalcem, ki se dnevno vozijo v mestno središče (Naeem in Ahmad, 2018). Med večjimi mesti v bližini sta še Lahore (11,13 milijona prebivalcev leta 2017) $102 \mathrm{~km}$ proti jugovzhodu in Faisalabad (3,2 milijona prebivalcev leta 2017) $106 \mathrm{~km}$ proti jugozahodu, s katerima ima Hafizabad prav tako vzpostavljene družbenogospodarske povezave.

Čeprav zgodovinski viri, ki se nanašajo na območje današnjega mesta Hafizabad, segajo vse do leta 327 pr. n. št., ko je Aleksan- 

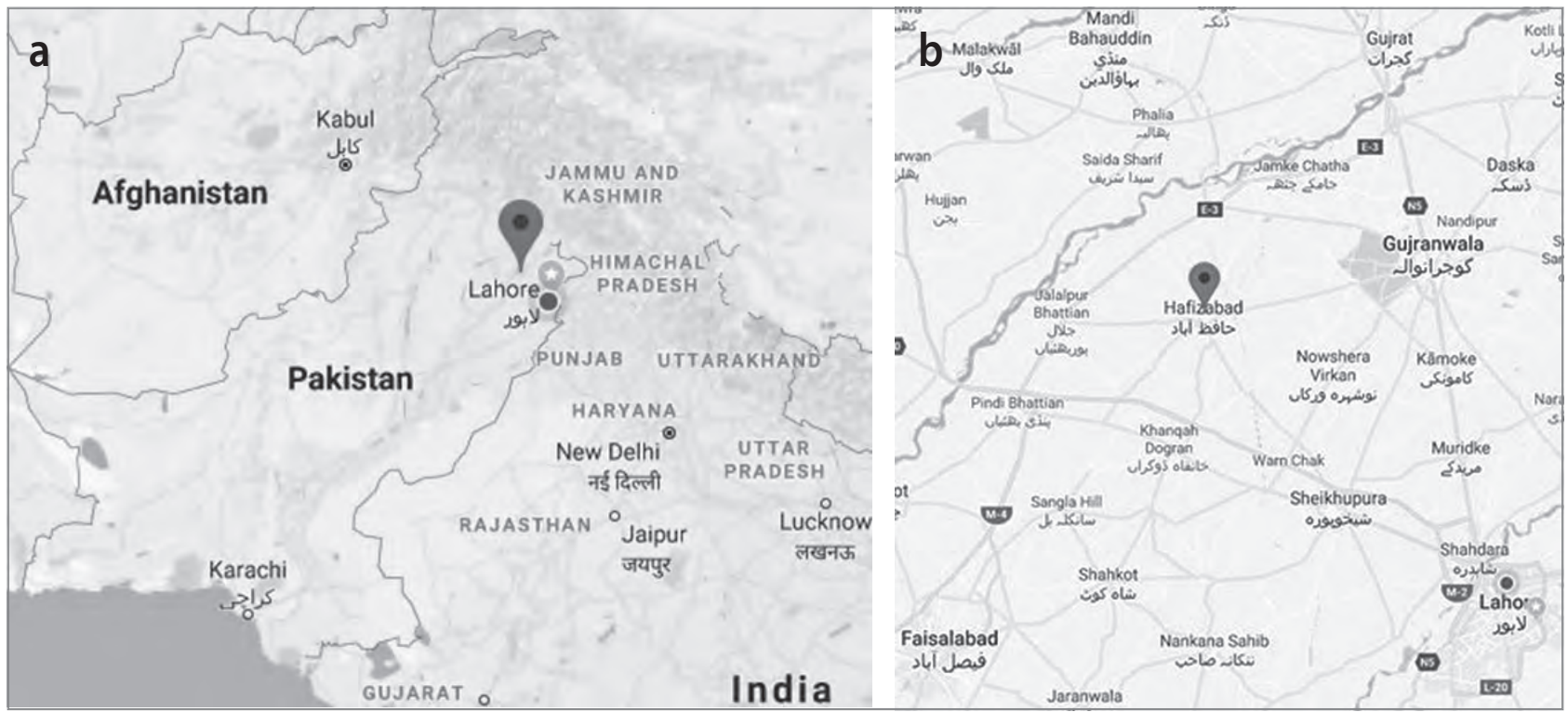

Slika 1: (a) Lokaciji Hafizabada v Pakistanu (vir: Google Maps, 2019) in (b) lokacija v regiji (vir: Google Maps, 2019).

der Veliki vdrl v Pundžab (Government of the Punjab, 2018), je mesto ustanovil šele Hafiz Meerak, ljubljenec mogulskega cesarja Akbarja I., ki je vladal med letoma 1542 in 1605. V starem, osrednjem delu mesta so zato še vedno vidne nekatere prvine mogulske mestne arhitekture iz 16. stoletja. Po padcu mogulskega cesarstva je bila celotna indijska podcelina do leta 1947 pod britansko kolonialno oblastjo. To obdobje je z viktorijansko arhitekturo pustilo neizbrisen pečat na tkivu mest v regiji Pundžab. Enako velja tudi za Hafizabad, kjer so v osrednjem delu še danes vidni ostanki mestne kolonialne arhitekture. Ta arhitekturna plast je del mestnega grajenega okolja iz obdobja pred odcepitvijo od Indije leta 1947. Po osamosvojitvi Pakistana se je večina hindujskih in sikhovskih prebivalcev preselila v Indijo, številni muslimani pa so se iz Indije preselili v Hafizabad. Te demografske spremembe so preobrazile mestno krajino, v kateri se je pojavila arhitektura, značilna za obdobje po odcepitvi (tj. od osamosvojitve do poznih devetdesetih let 20. stoletja). V okviru pakistanske državne stanovanjske politike, sprejete leta 2001, je bil stanovanjski sektor razglašen za prednostno področje, kar je spodbudilo razcvet nepremičninskega trga. Pri tem mala mesta, kot je Hafizabad, niso bila nobena izjema, spopadala pa so se tudi s posledicami nenačrtnega širjenja mestnega prostora $\mathrm{v}$ obliki stanovanjske gradnje zunaj meja mestnih občin, čeprav manj kot $\mathrm{v}$ večjih mestih. To je povzročilo nastanek tretje arhitekturne plasti v mestu: novejših načrtovanih stanovanjskih sosesk in ograjenih skupnosti. Različne zgodovinske arhitekturne plasti v Hafizabadu so prikazane na sliki 2 .

Z določitvijo različnih arhitekturnih plasti v mestu so lahko avtorji izbrali soseske za raziskavo na podlagi razlik v grajenem okolju. Razlike v urbani strukturi se deloma kažejo tudi v družbenogospodarskem položaju prebivalcev. Mesto se je večinoma širilo proti jugu, kjer so nastajale novogradnje, vključno z načrtovanimi stanovanjskimi soseskami. Za podrobnejšo raziskavo so bile izbrane štiri soseske v Hafizabadu z značilno urbano strukturo: dve v starejšem osrednjem delu mesta, ena v severnem delu mesta s polpravilno ulično mrežo in novejša soseska $\mathrm{v}$ južnem delu mesta. Urbana struktura teh štirih sosesk in podrobnosti o razpoložljivi infrastrukturi v njih so prikazane v preglednicah 2 in 3, njihova lokacija v mestu pa na sliki 3. Urbana struktura in razpoložljiva infrastruktura v vsaki soseski sta prikazani na sliki 4 .

\subsection{Podatki, spremenljivke in analiza}

Anketa je bila razdeljena na tri dele: informacije o posameznih gospodinjstvih in njihovem družbenogospodarskem položaju, značilnosti trenutne stanovanjske enote in značilnosti povpraševanja po stanovanjih. Vprašalnik je vključeval 16 vprašanj, izmed katerih so nekatera lahko vsebovala več podvprašanj. Šest vprašanj se je nanašalo na posameznika (njegovo starost, spol, zakonski stan, zaposlitev ter čas in oblika vsakodnevne poti v službo ali šolo), deset pa na posamezno gospodinjstvo (lastništvo vozila, vrsta stanovanja, razlog za izbor trenutnega bivališča, datum selitve, glavni razlog za selitev, lastništvo dodatne stanovanjske enote, število stanovanj v lasti, ali so prazna ali zasedena, vrsta posesti stanovanja, vrednost enote, višina najemnine, iskanje novega stanovanja, zaželena soseska, glavni razlog za izbor stanovanjske lokacije in zaželena oblika stanovanjske posesti). Razen števila stanovanj v lasti so vse spremenljivke kategorične. Vprašalnike so izpraševalci izpolnili med intervjuvanjem anketirancev.

V anketi so bili pridobljeni zelo natančni podatki o posamezni soseski. Velikost vzorcev in ocenjeni intervali zaupanja so bili 



Slika 2: Različne arhitekturne plasti v Hafizabadu (foto: Anwaar ul Haq)

Preglednica 2: Štiri proučevane soseske

\begin{tabular}{lllllllll}
\hline Št. & Soseska & Obdobje & Ulična mreža & $\begin{array}{l}\text { Št. prebivalcev } \\
(2018)\end{array}$ & $\begin{array}{l}\text { Bruto površina } \\
(\mathrm{v} \text { ha) }\end{array}$ & $\begin{array}{l}\text { Neto površina } \\
(\mathrm{v} \text { ha) }\end{array}$ & $\begin{array}{l}\text { Bruto gostota } \\
\text { prebivalstva/ } \\
\text { ha }\end{array}$ & $\begin{array}{l}\text { Neto gostota } \\
\text { prebivalstva/ } \\
\text { ha }\end{array}$ \\
\hline 1 & $\begin{array}{l}\text { Gali Hadži } \\
\text { Miradž Din }\end{array}$ & $\begin{array}{l}\text { Pred letom } \\
1947\end{array}$ & Nenačrtovana & 3.584 & 5,5 & 4,9 & 649,11 & 730,54 \\
\hline 2 & Šarifpura & $\begin{array}{l}\text { Pred letom } \\
1947\end{array}$ & Nenačrtovana & 3.298 & 31,5 & 27,4 & 104,64 & 120,26 \\
\hline 3 & Navab Colony & 1947-2000 & Polpravilna & 4.299 & 8,9 & 6,8 & 484,88 & 636,74 \\
\hline 4 & Hassan Town & Po letu 2000 & Pravilna & 7.861 & 22,7 & 20,1 & 346,73 & 514,64 \\
\hline
\end{tabular}

Preglednica 3: Urbana struktura izbranih sosesk

\begin{tabular}{|c|c|c|c|c|c|c|c|c|c|c|}
\hline \multirow[t]{2}{*}{ Št. } & \multirow[t]{2}{*}{ Soseska } & \multirow{2}{*}{$\begin{array}{l}\text { Prometne } \\
\text { povezave }\end{array}$} & \multirow[t]{2}{*}{ Vozlišča } & \multirow{2}{*}{$\begin{array}{l}\text { Razmerje med } \\
\text { prometnimi } \\
\text { povezavami in } \\
\text { vozlišči }\end{array}$} & \multirow{2}{*}{$\begin{array}{l}\text { Gostota križišč } \\
\text { (št. vozlišč/ha) }\end{array}$} & \multicolumn{4}{|c|}{ Infrastruktura } & \multirow{2}{*}{$\begin{array}{l}\text { Infrastruktura } \\
\text { na prebivalca }\end{array}$} \\
\hline & & & & & &  & 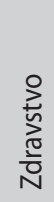 & 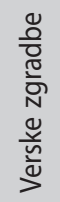 & $\frac{\stackrel{0}{\frac{0}{2}}}{\frac{2}{n}}$ & \\
\hline 1 & Gali Hadži Miradž Din & 66 & 59 & 1,12 & 10,73 & 43 & 1 & - & 44 & 0,012 \\
\hline 2 & Šarifpura & 190 & 168 & 1,13 & 5,33 & 119 & - & - & 119 & 0,036 \\
\hline 3 & Navab Colony & 44 & 35 & 1,26 & 3,93 & 66 & - & 1 & 67 & 0,016 \\
\hline 4 & Hassan Town & 83 & 45 & 1,84 & 1,98 & 72 & - & 1 & 73 & 0,009 \\
\hline
\end{tabular}




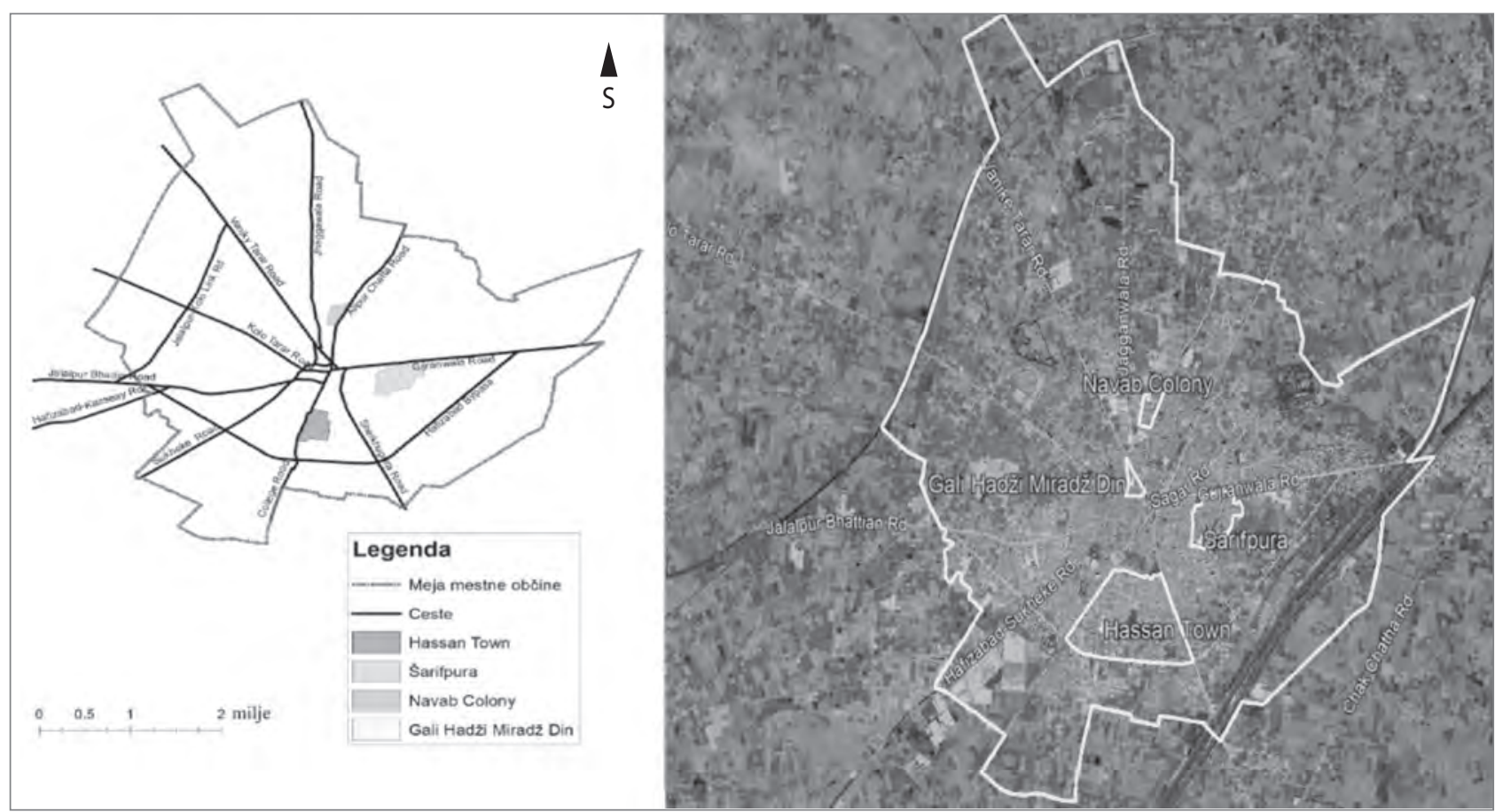

Slika 3: Lokacija proučevanih sosesk v Hafizabadu (slika: avtorji)

povzeti po Cochranu (1963), pri čemer so bili ti izračunani ločeno za vprašanja, ki so se nanašala na posameznike, in ločeno za vprašanja, ki so se nanašala na gospodinjstva. Intervali zaupanja za gospodinjstva so bili izračunani na podlagi povprečne velikosti gospodinjstev v mestu (tj. 6,6 osebe na podlagi podatkov popisa iz leta 2017. Posledično je bilo anketiranih $1,9 \%$ od skupno 19.042 prebivalcev vseh štirih proučevanih sosesk $(N)$. Pri delu vprašalnika, ki se je nanašal na gospodinjstva, so bili zbrani podatki za $12,7 \%$ vseh mestnih gospodinjstev. Interval zaupanja je tako pri posameznikih znašal $\pm 5,1 \%$, pri gospodinjstvih pa $\pm 4,8 \%$. Intervali zaupanja za posamezne proučevane soseske so navedeni v preglednici 4 , kjer so na podlagi skupnega vzorca 365 anketirancev povzete tudi velikosti vzorcev pri vsakem vprašanju.

Analiza je vključevala določitev frekvence odgovorov, ki so se nanašali na kategorične spremenljivke, in opisno statistiko, ki se je nanašala na število stanovanj v lasti (edino zvezno spremenljivko). Avtorji so jo opravili po validaciji in popravku rezultatov (rezultate so popravili predvsem pri soseski Navab Colony, pri kateri so nekatere vhodne podatke zaradi neustreznosti izločili iz vzorca).

\section{Rezultati}

V nadaljevanju so povzeti skupni izsledki, ki se nanašajo na kategorične kazalnike za vse štiri proučevane soseske. $45 \%$ anketirancev je bilo starih med 36 in 45 let, med vsemi pa je bilo kar $84 \%$ moških, saj je bilo zaradi kulturnih razlik v raziskavi težko uravnotežiti število moških in žensk. Podobno kot delež anketirancev srednjih let sta bila velika tudi deleža poročenih (82\%) in redno zaposlenih (78 \%).

Podobno kot pri mnogih drugih raziskavah, opravljenih v sosednjih državah in bližnjih regijah, je bil poudarek na gospodinjskem, in ne posameznikovem lastništvu vozil. V kulturah, kot je pakistanska, je namreč verjetneje, da si člani gospodinjstva vozila med seboj delijo. Tako je imelo $56 \%$ gospodinjstev, vključenih v anketo, v lasti po en motocikel, $22 \%$ jih je bilo brez avtomobila, $5 \%$ pa jih je imelo v lasti po en avtomobil. Velik delež gospodinjstev ( $87 \%$ ) je imel v lasti hiše, ki so jih sami zgradili, samo $12 \%$ pa jih je živelo v najemniških stanovanjih ali hišah. Kot je bilo za tako malo pakistansko mesto tudi pričakovati, je $41 \%$ gospodinjstev (npr. mladi pari) živelo v isti hiši kot starši in drugi sorodniki, kar je bil tudi najpomembnejši razlog za izbiro trenutnega bivališča. Bivanje v družinski hiši je poleg tega povezano $s$ še dvema, malo manj pomembnima razlogoma: $16 \%$ se jih je za trenutno bivališče odločilo, ker je v prijetni soseski, $14 \%$ pa se jih je tako odločilo zaradi cenovne ugodnosti. Velik delež anketirancev $(73 \%)$ je do službe ali šole potreboval manj kot 30 minut, pri čemer so do tja najpogosteje pešačili (40 \%) ali so se peljali z motociklom (40\%). Več kot tretjina gospodinjstev se je $\mathrm{v}$ času izvajanja ankete preselila in avtorji so prav na tem vzorcu proučevali razloge za selitev in izbiro stanovanjske lokacije. Največ gospodinjstev $(42 \%)$ se je 

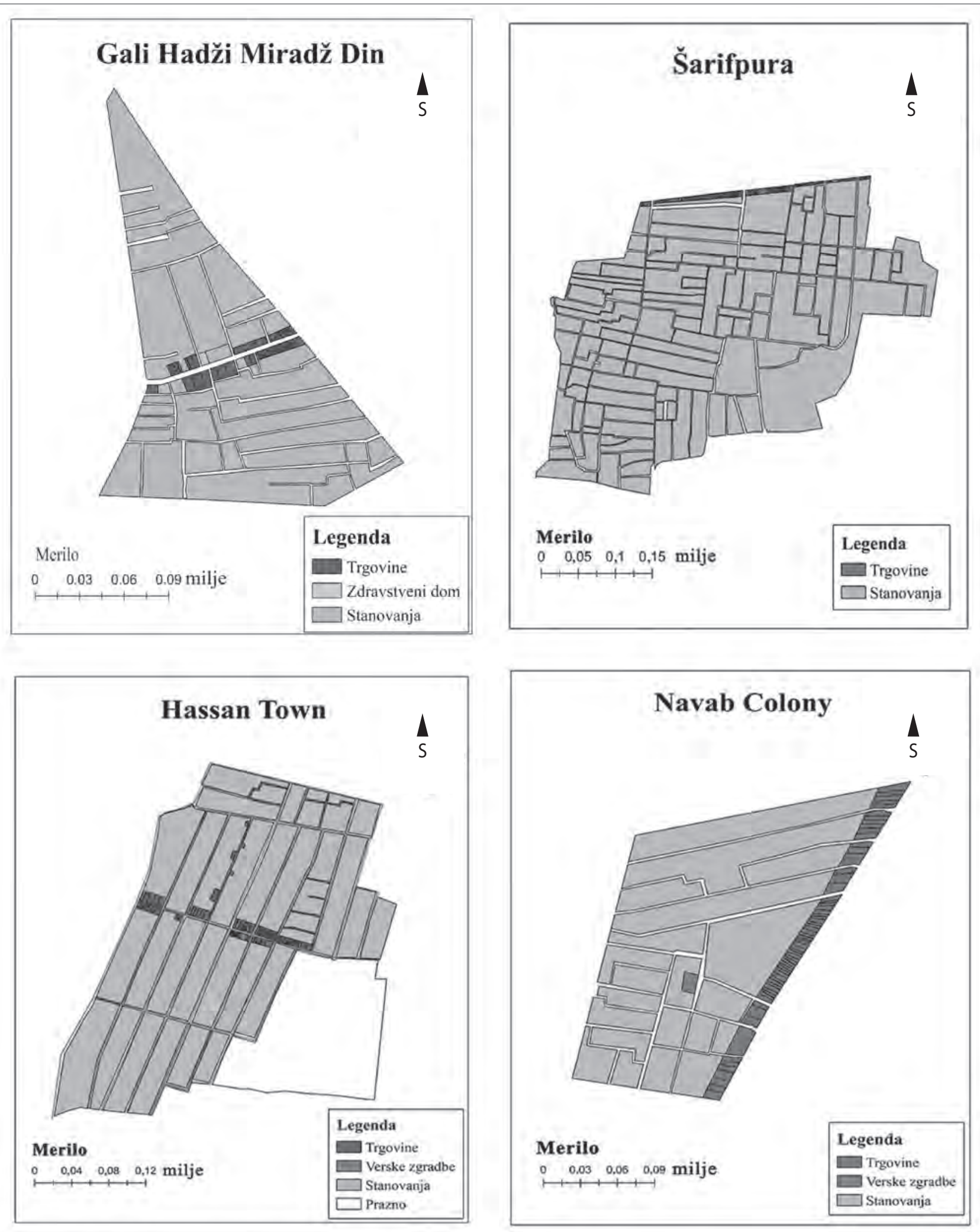

Slika 4: Namenska raba prostora v izbranih soseskah (slika: avtorji) 
Preglednica 4: Značilnosti raziskovalnega vzorca na ravni sosesk in skupni vzorec

\begin{tabular}{|c|c|c|c|c|c|c|c|c|c|}
\hline 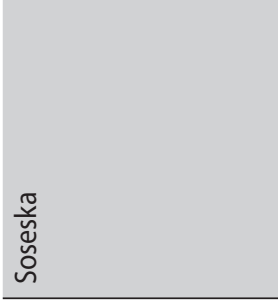 & 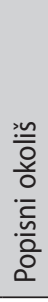 & 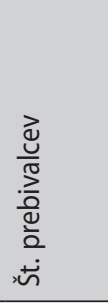 & 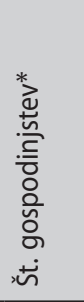 & 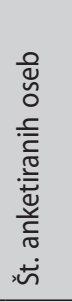 & 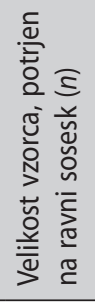 & 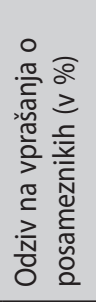 & 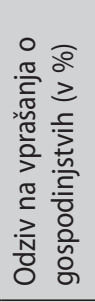 & 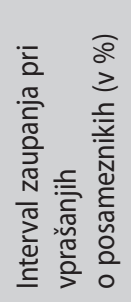 & 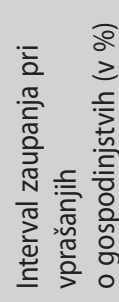 \\
\hline Hassan Town & 12 & 7.861 & 1.191 & 100 & 100 & 1,27 & 8,40 & 9,74 & 9,38 \\
\hline Šarifpura & 10 & 3.298 & 500 & 100 & 100 & 3,03 & 20,00 & 9,65 & 8,77 \\
\hline Gali Hadži Miradž Din & 6 & 3.584 & 543 & 100 & 100 & 2,79 & 18,42 & 9,66 & 8,86 \\
\hline Navab Colony & 5 & 4.299 & 651 & 98 & 65 & 1,51 & 9,98 & 12,06 & 11,54 \\
\hline Skupni vzorec & - & 19.042 & 2.885 & 398 & 365 & 1,92 & 12,65 & 5,08 & 4,79 \\
\hline
\end{tabular}

Opomba: * Izračunano na podlagi povprečne velikosti gospodinjstev v Hafizabadu (6,6 osebe)

zadnjič preselilo pred dvema do desetimi leti. Za $15 \%$ anketirancev je bil najpomembnejši razlog za izbor nove lokacije vrsta bivališča ali soseska, $65 \%$ pa jih na to vprašanje sploh ni odgovorilo, saj se pred tem še nikoli niso preselili. Prevoz skoraj za nobeno anketirano gospodinjstvo ni bil razlog za selitev $(0,27 \%)$ in samo $18 \%$ gospodinjstev je imelo v lasti še eno bivališče. $V$ približno polovici teh bivališč je nekdo živel. Samo 11 \% gospodinjstev je živelo v najemu, preostala pa so živela v svoji hiši. Vrednost več kot polovice teh hiš je znašala med 1,5 in 3 milijoni PKR. Od 11 \% gospodinjstev, ki so imela hišo v najemu, jih je $68 \%$ za najemnino plačevalo manj kot tretjino svojega dohodka. V prihodnosti namerava $28 \%$ gospodinjstev poiskati novo hišo. Več kot polovica jih želi še naprej živeti v isti soseski, $45 \%$ pa jih bo stanovanje iskalo v drugi soseski v Hafizabadu. Preostalih 5 \% jih želi Hafizabad zapustiti in se preseliti v drugo mesto, najverjetneje Lahore. Dobre storitve in komunalna oprema v soseski so najpomembnejši razlog za selitev za $23 \%$ gospodinjstev, na drugem mestu pa je dostopna cena (za $20 \%$ anketirancev). Bližino delovnega mesta je kot razlog za selitev navedlo $17 \%$ gospodinjstev, $91 \%$ pa bi se jih v prihodnosti najraje preselilo v lastno hišo.

Zgoraj opisani podatki se nanašajo na celoten vzorec anketirancev iz vseh štirih proučevanih sosesk. Za boljše razumevanje vloge različnih urbanih struktur in okolij na odločitve anketirancev v posamezni soseski so avtorji odgovore, povezane $s$ kategoričnimi spremenljivkami, analizirali ločeno za vsako proučevano sosesko in jih ponazorili z grafi. Nekateri izmed njih so prikazani na sliki 6. Najmlajši anketiranci so prihajali iz soseske Hassan Town (44 \%), anketiranci iz sosesk Gali Hadži Miradž Din in Šarifpura pa so bili starejši (25 \% jih je bilo starih 46 let ali več). Največji delež žensk je prihajal iz soseske Hassan Town (32\%), najmanjši delež neporočenih anketirancev pa je prihajal iz soseske Navab Colony (28 \%). Soseska Gali Hadži Miradž Din je imela največji delež zaposlenih s polnim delovnim časom (84 \%), največji delež posa- meznikov, ki so imeli v lasti motocikel (62\%), in največji delež lastnikov avtomobilov. Delež samozgrajenih hiš je podoben v treh izmed štirih sosesk (Gali Hadži Miradž Din, Šarifpura in Hassan Town), in sicer od 86 do 88 \%, največji delež podnajemnikov pa je prihajal iz soseske Gali Hadži Miradž Din (10\%). Največ anketirancev v celotnem vzorcu je živelo v družinski hiši skupaj s starši in drugimi sorodniki. Cenovna dostopnost, bližina delovnega mesta in prijetna soseska so najpomembnejši dejavniki, zaradi katerih anketiranci prebivajo na trenutni lokaciji, socialno-kulturni status anketirancev, ki so navedli te tri razloge, pa je malce drugačen od statusa drugih anketirancev v celotnem vzorcu. Najkrajšo pot v službo ali šolo so imeli anketiranci v soseski Hassan Town, pri čemer jih je $79 \%$ navedlo, da jim vzame manj kot pol ure. Ta delež v soseski Navab Colony pade na $67 \%$, v tej soseski tudi najmanj ljudi v službo ali šolo hodi peš (28\%). Polovica gospodinjstev v soseski Hassan Town se je že preselila, v soseski Šarifpura pa je to do zdaj storilo samo 27 \% gospodinjstev. Več kot polovica gospodinjstev v soseski Navab Colony se je preselila v zadnjih dveh letih, 40 \% gospodinjstev v soseski Gali Hadži Miradž Din pa se je preselilo že pred več kot desetimi leti. Dejavniki, povezani s prevozom, so bili pomembni samo za 1,5 \% gospodinjstev v soseski Navab Colony, v drugih pa niso bili razlog za selitev. Dodatno stanovanjsko enoto ima v lasti največ anketirancev v soseski Navab Colony (28\%), v vseh štirih soseskah pa ima skoraj enak delež anketirancev v lasti hišo, v kateri stanujejo (88-90 \%). Po navedbah anketirancev so najcenejše hiše v soseski Hassan Town (29\%), najdražje pa v soseski Navab Colony (16\%). V soseski Hassan Town 91 \% anketirancev zapravi manj kot tretjino svojega dohodka za najemnino. Največji delež gospodinjstev, ki se nameravajo preseliti, je v Šarifpuri (32 \%). 41 do 54 \% vseh anketiranih gospodinjstev namerava ostati v isti soseski tudi v prihodnje, pri čemer so gospodinjstva v soseski Hassan Town pokazala najmanj zanimanja za selitev drugam ( $37 \%)$.Za gospodinjstva, ki se želijo preseliti v drugo mesto, je bolj verjetno, da bodo za 


\begin{tabular}{|c|c|c|c|c|c|c|}
\hline Povprečna stanovanjska & \multicolumn{2}{|c|}{ Veljavni podatki } & \multicolumn{2}{|c|}{ Manjkajoči podatki } & \multicolumn{2}{|c|}{ Skupno } \\
\hline & $N$ & Odstotek & $N$ & Odstotek & $N$ & Odstotek \\
\hline & 350 & $95,9 \%$ & 15 & $4,1 \%$ & 365 & $100,0 \%$ \\
\hline \multicolumn{7}{|l|}{ Opisna statistika } \\
\hline \multirow{2}{*}{ Aritmetična sredina } & & Statistika & 122,33 & \multirow{2}{*}{ - Stand. odklon } & Statistika & 50,183 \\
\hline & & Stand. napaka & 2,682 & & Stand. napaka & - \\
\hline \multirow{2}{*}{$\begin{array}{l}\text { 95-odstotni interval za- } \\
\text { upanja pri aritmetični } \\
\text { sredini }\end{array}$} & Spodnja meja & \multirow{2}{*}{ Statistika } & 117,06 & \multirow{2}{*}{ Najmanjši } & Statistika & 20 \\
\hline & Zgornja meja & & 127,61 & & Stand. napaka & - \\
\hline \multirow{2}{*}{$\begin{array}{l}\text { 5-odstotna modificirana } \\
\text { aritmetična sredina }\end{array}$} & & Statistika & 118,49 & \multirow{2}{*}{ - Največji } & Statistika & 379 \\
\hline & & Stand. napaka & - & & Stand. napaka & - \\
\hline \multirow{2}{*}{ Mediana } & & Statistika & 126,00 & \multirow{2}{*}{ - Razpon } & Statistika & 359 \\
\hline & & Stand. napaka & - & & Stand. napaka & - \\
\hline \multirow{2}{*}{ Varianca } & & Statistika & 2518,302 & \multirow{2}{*}{ - Kvartilni razpon } & Statistika & 37 \\
\hline & & Stand. napaka & - & & Stand. napaka & - \\
\hline \multirow{2}{*}{ Sploščenost } & & Statistika & 3,989 & \multirow{2}{*}{ - Asimetrija } & Statistika & 1,428 \\
\hline & & Stand. napaka & 0,260 & & Stand. napaka & 0,130 \\
\hline \multicolumn{7}{|l|}{ Test normalnosti } \\
\hline \multirow[t]{3}{*}{ Kategorija } & \multicolumn{3}{|c|}{ Kolmogorov-Smirnov } & \multicolumn{3}{|c|}{ Shapiro-Wilk } \\
\hline & Statistika & $\mathrm{df}$ & $p$ & Statistika & df & $p$ \\
\hline & 0,242 & 350 & $<0,001$ & 0,875 & 350 & $<0,001$ \\
\hline
\end{tabular}

Slika 5: Opisna statistika in test normalne porazdelitve za stanovanjsko površino anketirancev

to izbrala Lahore kot pa katero drugo, bolj oddaljeno mesto. V soseski Gali Hadži Miradž Din je najpomembnejši razlog za izbiro lokacije prihodnjega stanovanja razpoložljivost storitev in komunalne infrastrukture (31\%), v Šarifpuri pa so glavni razlogi za to cenovna dostopnost (22\%), razpoložljivost storitev in komunalne infrastrukture (21\%) ter bližina prijateljev in sorodnikov $(20 \%)$. Cenovna dostopnost $(30 \%)$ in bližina delovnega mesta $(29 \%)$ sta daleč najpomembnejša razloga v soseski Hassan Town, v soseski Navab Colony pa anketiranci iščejo predvsem lokacijo z ustreznimi storitvami in komunalno infrastrukturo (29\%) ter mirnim okoljem (23\%). Med 85 in $99 \%$ anketirancev iz vseh štirih sosesk bi se rado v prihodnje preselilo v hišo, ki bi bila v njihovi lasti.

Anketa je vključevala samo eno zvezno spremenljivko: stanovanjsko površino v lasti posameznega gospodinjstva. Opisni statistični podatki, povezani s tem vprašanjem, so prikazani na sliki 5. Od skupno 365 anketiranih gospodinjstev jih je na to vprašanje odgovorilo 350 . Površine so različne, od $20 \mathrm{~m}^{2}$ do $379 \mathrm{~m}^{2}$, povprečna površina je $122,3 \mathrm{~m}^{2}$, standardna napaka pa je znašala le 2,68 $\mathrm{m}^{2}$. Razpon površin je tako velik, ker je nekaj gospodinjstev poročalo tudi o tako veliki površini, kot je $359 \mathrm{~m}^{2}$. Rezultati Kolmogorov-Smirnovega in Shapiro-Wilkovega testa so pokazali, da so vrednosti statistične značilnosti $p$ nižje od 0,001 , kar pomeni, da porazdelitev ni normalna.

\section{Razprava}

Kot že veliko dosedanjih raziskav te problematike so tudi v tej raziskavi avtorji uporabili kvantitativne metode, $s$ katerimi so proučevali odločitve prebivalcev Hafizabada glede lokacije svojega stanovanja. Kot v prejšnjih raziskavah je bila tudi v tej raziskavi soseska izbrana za osnovno enoto analize. Podatki iz popisa prebivalstva v soseskah Hafizabada so bili uporabljeni kot okvir za vzorčenje. Kot pri večini podobnih dosedanjih študij je izbor štirih sosesk v mestu temeljil na razlikah v urbani strukturi in obdobjih, v katerih so bile zgrajene. Ker je bila v literaturi nakazana nizka stopnja odziva na metode posrednega zbiranja podatkov (tj. anket, poslanih po pošti), so se avtorji raje odločili za neposredno anketiranje na terenu. Stopnja odziva je znašala 1,92 \% in je podobna stopnjam, doseženim v prejšnjih raziskavah, opravljenih $\mathrm{v}$ razvitem svetu. Iz razprave v nadaljevanju je razvidno, da je izbrana metodologija skladna z metodologijo, uporabljeno $\mathrm{v}$ številnih prejšnjih raziskavah podobne tematike $\mathrm{v}$ razvitih državah, kar kaže na zanesljivost izsledkov te raziskave.

Izsledki razkrivajo, da je za večino anketirancev, ki imajo v lasti hišo, ki so jo sami zgradili in v njej živijo že več kot dve leti, glavni razlog za to, da v njej živijo, dejstvo, da je v lasti njihove družine. Velik delež lastniških stanovanj ali hiš v Pakistanu je 




Trenutni status stanovanjske enote

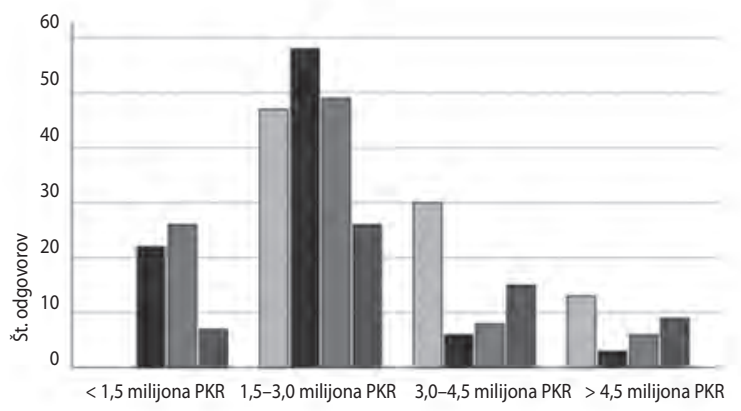

Dejanska vrednost hiše na nepremičninskem trgu



Iščete novo stanovanje?

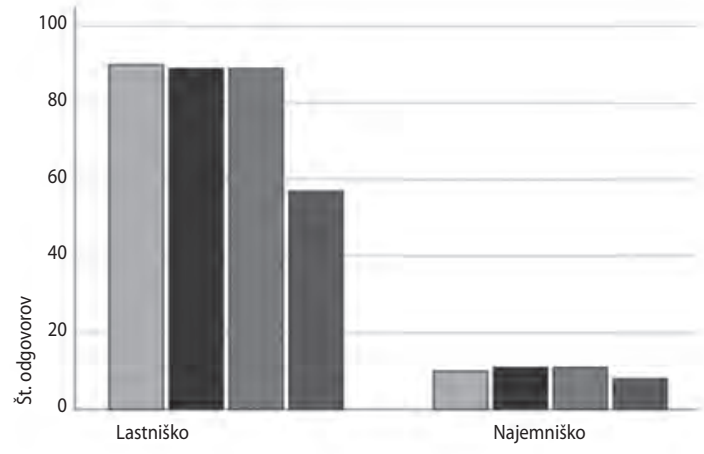

Oblika posesti stanovanja

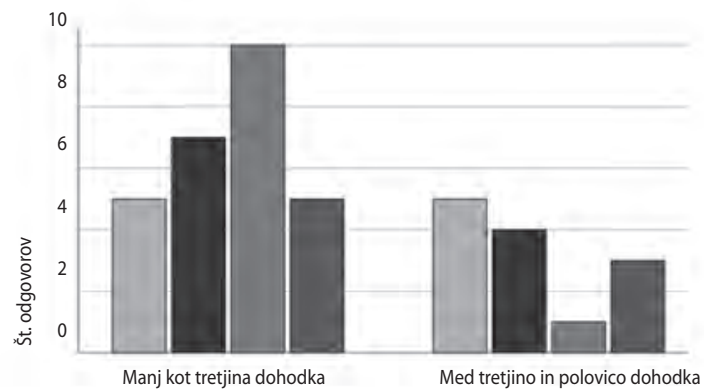

Višina najemnine

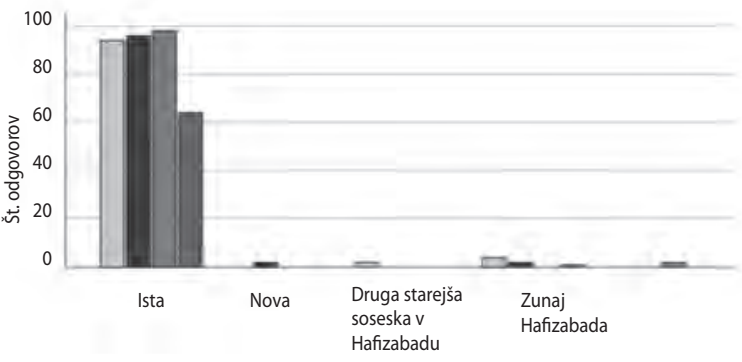

Zaželena soseska

Slika 6: Izbrani grafi, ki prikazujejo frekvence odgovorov na analizirana vprašanja v štirih soseskah (vir: avtorji)

v ostrem nasprotju z razvitim svetom. Povečan delež lastniških stanovanj zmanjšuje splošno stanovanjsko mobilnost, posledično pa ima za večino anketirancev družinsko stanovanjsko premoženje odločilno vlogo pri odločanju o tem, kjer bodo živeli. Lastništvo hiše v pakistanski družbi kaže družbenogospodarski položaj, kar ljudi odvrača od najema stanovanj. Tudi sistem razširjenih družin kot prevladujoč način življenja številnih gospodinjstev v državah v razvoju je lahko razlog za to, da se ljudje raje odločajo za to, da bodo živeli v stanovanju ali hiši, ki je v lasti njihove družine. Ti izsledki se ne ujemajo z ugotovitvami raziskav, opravljenih v razvitem svetu.
Bližina delovnega mesta se ni izkazala za enega glavnih razlogov za izbiro trenutne stanovanjske lokacije. To je lahko posledica majhnosti mesta, v katerem v nasprotju z večjimi mesti večina služb ni daleč od posameznikovega doma. Približno tri četrtine anketirancev do službe potrebuje manj kot pol ure, pri čemer jih približno $40 \%$ najraje pešači. To kaže na dobro ravnovesje med številom stanovanj in delovnih mest ter bi bilo lahko reprezentativno tudi za druga mala mesta v Pakistanu, ki so večinoma nastala organsko, brez načrtovanja. Poleg tega je to lahko razlog, zakaj bližina službe ni med glavnimi dejavniki, ki vplivajo na izbiro stanovanjske lokacije v malem mestu. To do- 
datno potrjuje ugotovitev, da prevoz ni bil odločilni dejavnik za nobeno od gospodinjstev, ki so se v preteklosti že preselila. Ti izsledki se ne ujemajo z izsledki raziskav, opravljenih v razvitem svetu. Avtorji so podobno raziskavo (še neobjavljena) opravili tudi v Lahoreju (tj. večjem mestnem središču), kjer so ugotovili, da je povprečna oddaljenost delovnega mesta od stanovanjske soseske $8,4 \mathrm{~km}$. Če bi tudi med gospodinjstvi v tem mestu proučevali dejavnike, ki vplivajo na izbiro stanovanjske lokacije, bi verjetno dobili drugačne rezultate. Majhen pomen prevoza ali oddaljenosti delovnega mesta pri izbiri lokacije stanovanja $\mathrm{v}$ malih mestih kaže, da močan premik $\mathrm{k}$ tranzitno usmerjenemu razvoju morda ne bi bila pametna strategija za mala mesta v državah v razvoju.

Druga pomembna ugotovitev te raziskave je povezana z nameravano preselitvijo v drugo mesto. Čeprav delež prebivalcev, ki se nameravajo izseliti iz mesta, znaša samo $5 \%$, je ugotovitev, da se ljudje želijo preseliti v večja mesta, zlasti Lahore, pomembna. Čeprav razlogi za to niso znani, bi morale pristojne občinske službe poskušati oblikovati politiko, ki bi zajezila urbanizacijo $\mathrm{v}$ večjih pakistanskih mestih. Lahore je že tako prenatrpan, nadaljnje priseljevanje iz bližnjih manjših mest pa bo razmere samo še poslabšalo in še bolj obremenilo obstoječo infrastrukturo.

Glavna omejitev raziskave je povezana z dejstvom, da se je samo tretjina anketirancev v preteklosti že preselila in je tako lahko povedala, kaj je bil odločilni dejavnik pri izbiri lokacije njihovega stanovanja. Vzrok za tako majhen delež je visoka stopnja stanovanjskega lastništva v Pakistanu. Avtorji so preostale anketirance spraševali o tem, ali se $\mathrm{v}$ prihodnje nameravajo preseliti in kateri so odločilni dejavniki, ki bodo vplivali na njihovo izbiro stanovanjske lokacije. Izkazalo se je, da samo četrtina anketirancev išče novo stanovanje. Poleg tega so se odgovori na ta vprašanja nanašali na nedoločen čas v prihodnosti, zaradi česar obstaja možnost, da bodo ob dejanski preselitvi drugačni. Opisano pomanjkljivost zbranih podatkov so avtorji odpravili tako, da so anketirance povprašali o njihovih trenutnih namerah glede preselitve, zaradi česar navedena omejitev ne bo imela večjega vpliva na zanesljivost izsledkov.

\section{Sklep}

Metodologija navedene raziskave je bila skrbno oblikovana in se ujema z metodologijo, uporabljeno v številnih tovrstnih prejšnjih raziskavah, opravljenih v razvitem svetu. Zaradi velikega deleža lastniških domov v Pakistanu je bil glavni dejavnik, ki je vplival na izbiro lokacije stanovanja, trenutno stanovanjsko premoženje družine. Dostop do prometne infrastrukture in bližina delovnega mesta se nista izkazala za pomembna dejavnika, kar je lahko posledica majhnosti Hafizabada. Poleg tega je ta ugotovitev povezana tudi z dejstvom, da so mala pakistanska mesta kompaktnejša, gosteje pozidana in imajo dobro ravnovesje med številom služb in stanovanj v primerjavi $\mathrm{z}$ večjimi mesti. Na podlagi teh ugotovitev lahko odgovorne oblasti bolje oblikujejo urbanistično in prometno politiko ter $s$ tem dosežejo cilje tranzitno usmerjenega razvoja, učinkovito rešujejo vprašanja, povezana s socialnimi stanovanji, in obvladujejo urbanizacijo v večjih mestih. Raziskava kaže, da v malem mestu z 245.784 prebivalci (po podatkih iz leta 2017) dejavniki, povezani s prevozom, nimajo pomembne vloge pri izbiri stanovanjske lokacije. Stanje v velikih mestnih središčih pa je lahko drugačno in bi ga bilo treba temeljiteje proučiti, zaradi česar bi bilo treba tudi v večjih mestih izvesti podobne raziskave. $V$ raziskavi, navedeni v tem članku, so rezultati ankete omenjeni samo opisno, za določitev povezav med spremenljivkami in za nadaljnjo potrditev končnih izsledkov pa so potrebne nadaljnje empirične raziskave. Avtorji predlagajo, da se podobne raziskave opravijo tudi $\mathrm{v}$ drugih malih mestih $\mathrm{v}$ državah v razvoju, pri čemer bi moral biti poseben poudarek na mlajših prebivalcih in zlasti mlajših parih ali družinah, saj bodo njihove odločitve pomembno vplivale na prihodnje potovalne navade mestnih prebivalcev.

Atif Bilal Aslam, Department of City and Regional Planning, University of Engineering and Technology Lahore, Pakistan E-naslov: atif.aslam@uet.edu.pk

Houshmand E. Masoumi, Centre for Technology and Society, Technical University of Berlin, Nemčija

E-naslov:masoumi@ztg.tu-berlin.de

Nida Naeem, Department of City and Regional Planning, University of Engineering and Technology Lahore, Pakistan

E-naslov: nida.naeem64@yahoo.com

Mohammad Ahmad, Department of City and Regional Planning, University of Engineering and Technology Lahore, Pakistan E-naslov:ahmadnoul786@gmail.com

\section{Viri in literatura}

Ahmad, N. (1992): Choice of location and mobility behaviour of migrant households in a third world city. Urban Studies, 29(7), str. 11471157. DOI: 10.1080/00420989220081091

Ahmad, N. (1993): Choice of neighbourhoods by mover households in Karachi. Urban Studies, 30(7), str. 1257-1270. DOI: 10.1080/00420989320081161

Ahmad, N., in Anjum, G. A. (2012): Legal and institutional perplexities hampering the implementation of urban development plans in Pakistan. Cities, 29(4), str. 271-277. DOI: 10.1016/j.cities.2011.07.006

Balbontin, C., Ortúzar, J. de D., in Swait, J. D. (2015): A joint best-worst scaling and stated choice model considering observed and unobserved heterogeneity: An application to residential location choice. Journal of Choice Modelling, 16, str. 1-14. DOI: 10.1016/j.jocm.2015.09.002

Bayoh, I., Irwin, E. G., in Haab, T. (2006): Determinants of residential location choice: How important are local public goods in attracting 
homeowners to central city locations? Journal of Regional Science, 46(1), str. 97-120. DOI: 10.1111/j.0022-4146.2006.00434.x

Biying, Y., Zhang, J., in Fujiwara, A. (2012): Analysis of the residential location choice and household energy consumption behavior by incorporating multiple self-selection effects. Energy Policy, 46, str. 319-334. DOI: 10.1016/j.enpol.2012.03.067

Buczkowska, S., in Lapparent, M. de (2014): Location choices of newly created establishments: Spatial patterns at the aggregate level. Regional Science and Urban Economics, 48, str. 68-81.

DOI: 10.1016/j.regsciurbeco.2014.05.001

Cao, X., Handy, S. L., in Mokhtarian, P. L. (2006a): The influences of the built environment and residential self-selection on pedestrian behavior: Evidence from Austin, TX. Transportation, 33(1), str. 1-20.

DOI: $10.1007 / s 11116-005-7027-2$

Cao, X., Mokhtarian, P. L., in Handy, S. L. (2006b): Neighborhood design and vehicle type choice: Evidence from northern California. Transportation Research Part D: Transport and Environment, 11(2), str. 133-145. DOI: 10.1016/j.trd.2005.10.001

Cao, X., Mokhtarian, P. L., in Handy, S. L. (2009): Examining the impacts of residential self-selection on travel behaviour: A focus on empirical findings. Transport Reviews, 29(3), str. 359-395. DOI: 10.1080/01441640802539195

Cao, X., Xu, Z., in Fan, Y. (2010): Exploring the connections among residential location, self-selection, and driving: Propensity score matching with multiple treatments. Transportation Research Part A: Policy and Practice, 44(10), str. 797-805. DOI: 10.1016/j.tra.2010.07.010

Chiarazzo, V., Coppola, P., Dell'Olio, L., Ibeas, A., in Ottomanelli, M. (2014): The effects of environmental quality on residential choice location. Procedia - Social and Behavioral Sciences, 162, str. 178-187. DOI: 10.1016/j.sbspro.2014.12.198

Choocharukul, K., Van, H. T., in Fujii, S. (2008): Psychological effects of travel behavior on preference of residential location choice. Transportation Research Part A: Policy and Practice, 42(1), str. 116-124. DOI: 10.1016/j.tra.2007.06.008

Choudhury, C. F., in Ayaz, S. B. (2015): Why live far? - Insights from modeling residential location choice in Bangladesh. Journal of Transport Geography, 48, str. 1-9. DOI: 10.1016/j.jtrangeo.2015.08.001

Cochran, W. G. (1963): Sampling techniques. New York, John Wiley and Sons.

Connor, K. M. (1989): Factors in the residential choices of self-settled Afghan refugees in Peshawar, Pakistan. International Migration Review, 23(4), str. 904-932. DOI: 10.1177/019791838902300408

Ettema, D., in Nieuwenhuis, R. (2017): Residential self-selection and travel behaviour: What are the effects of attitudes, reasons for location choice and the built environment? Journal of Transport Geography, 59, str. 146-155. DOI: 10.1016/j.jtrangeo.2017.01.009

Fatmi, M. R., Chowdhury, S., in Habib, M. A. (2017): Life history-oriented residential location choice model: A stress-based two-tier panel modeling approach. Transportation Research Part A: Policy and Practice, 104, str. 293-307. DOI: 10.1016/j.tra.2017.06.006

Frank, L. D., Saelens, B. E., Powell, K. E., in Chapman, J. E. (2007): Stepping towards causation: Do built environments or neighborhood and travel preferences explain physical activity, driving, and obesity? Social Science \& Medicine, 65(9), str. 1898-1914.

DOI: 10.1016/j.socscimed.2007.05.053

Frenkel, A., Bendit, E., in Kaplan, S. (2013): Residential location choice of knowledge-workers: The role of amenities, workplace and lifestyle. Cities, 35, str. 33-41. DOI: 10.1016/j.cities.2013.06.005
Ge, J., in Hokao, K. (2006): Research on residential lifestyles in Japanese cities from the viewpoints of residential preference, residential choice and residential satisfaction. Landscape and Urban Planning, 78(3), str. 165-178. DOI: 10.1016/j.landurbplan.2005.07.004

Google (2019) Zemljevid proučevanega območja. Dostopno na: https:// bit.ly/2XIZbyt (sneto: 17. 2. 2019).

Government of Pakistan (2017): 6th Population and Housing Census 2017. Islamabad.

Government of the Punjab (2018): Punjab portal. Dostopno na: https:// www.punjab.gov.pk/hafizabad_history (sneto 25. 6. 2018).

Hameed, R., in Nadeem, O. (2008): Challenges of implementing urban master plans: The Lahore experience. International Journal of Humanities and Social Sciences, 2(12), str. 1297-1304.

Handy, S. L., in Clifton, K. J. (2001): Local shopping as a strategy for reducing automobile travel. Transportation, 28(4), str. 317-346.

Heldt, B., Gade, K., in Heinrichs, D. (2016): Determination of attributes reflecting household preferences in location choice models. Transportation Research Procedia, 19, str. 119-134. DOI: 10.1016/j.trpro.2016.12.073

Humphreys, J., in Ahern, A. (2017): Is travel based residential self-selection a significant influence in modal choice and household location decisions? Transport Policy, 75, str. 150-160.

DOI: 10.1016/j.tranpol.2017.04.002

Ibrahim, M. R. (2017): How do people select their residential locations in Egypt? The case of Alexandria. Cities, 62, str. 96-106. DOI: 10.1016/j.cities.2016.12.012

Jun, M.-J., Ha, S.-K., in Jeong, J.-E. (2013): Spatial concentrations of Korean Chinese and determinants of their residential location choices in Seoul. Habitat International, 40, str. 42-50.

DOI: 10.1016/j.habitatint.2013.02.002

Kim, J. H., Pagliara, F., in Preston, J. (2005): The intention to move and residential location choice behaviour. Urban Studies, 42(9), str. 16211636. DOI: $10.1080 / 00420980500185611$

Kitamura, R., Mokhtarian, P. L., in Laidet, L. (1997): A micro-analysis of land use and travel in five neighborhoods in the San Francisco Bay area. Transportation, 24(2), str. 125-158.

Lall, S. V., Suri, A., in Deichmann, U. (2006): Household savings and residential mobility in informal settlements in Bhopal, India. Urban Studies, 43(7), str. 1025-1039. DOI: 10.1080/00420980500406744

Masoumi, H. E. (2013): Residential self-selection and its effects on urban commute travels in Iranian cities compared to US, UK, and Germany. International Journal of Social Sciences, 7(5), str. 877-881.

Molugaram, K., in Rao, K. V. (2005): A stated preference residential location choice model in Indian context (= Australasian Transport Research Forum (ATRF) 28). Sydney, Curtin University.

Naeem, N., in Ahmad, M. (2018): Residential location choice behaviour: A case study of city Hafizabad-Punjab. Lahore, University of Engineering and Technology.

Næss, P. (2009): Residential self-selection and appropriate control variables in land use: Travel studies. Transport Reviews, 29(3), str. 293-324. DOI: 10.1080/01441640802710812

Næss, P. (2013): Residential location, transport rationales and daily-life travel behavior: The case of Hangzhou Metropolitan Area, China. Progress in Planning, 79, str. 1-50. DOI: 10.1016/j.progress.2012.05.001

Painter, K. (1996): The influence of street lighting improvements on crime, fear and pedestrian street use, after dark. Landscape and Urban Planning, 35(2-3), str. 193-201. DOI: 10.1016/0169-2046(96)00311-8 
Palma, A. de, Motamedi, K., Picard, N., in Waddell, P. (2005): A model of residential location choice with endogenous housing prices and traffic for the Paris region. European Transport, 31, str. 67-82.

Park, J., in Kim, K. (2016): The residential location choice of the elderly in Korea: A multilevel logit model. Journal of Rural Studies, 44, str. 261271. DOI: 10.1016/j.jrurstud.2016.02.009

Patacchini, E., in Arduini, T. (2016): Residential choices of young Americans. Journal of Housing Economics, 34, str. 69-81.

DOI: 10.1016/j.jhe.2016.08.003

Pinjari, A. R., Pendyala, R. M., Bhat, C. R., in Waddell, P. A. (2011): Modeling the choice continuum: An integrated model of residential location auto ownership, bicycle ownership, and commute tour mode choice decisions. Transportation, 38(6), str. 933.

DOI: 10.1007/s11116-011-9360-y

Schwanen, T., in Mokhtarian, P. L. (2004): The extent and determinants of dissonance between actual and preferred residential neighborhood type. Environment and Planning B: Planning and Design, 31(5), str. 759784. DOI: 10.1068/b3039

Schwanen, T., in Mokhtarian, P., L. (ur.) (2003): Does dissonance between desired and current residential neighbourhood type affect individual travel behaviour? An empirical assessment from the San Francisco Bay area. Earlier faculty research. Berkeley, CA, UC Berkeley. Dostopno na: https:// escholarship.org/uc/item/26k8w6xf (sneto 13. 5. 2019).

Sener, I. N., Pendyala, R. M., in Bhat, C. R. (2011): Accommodating spatial correlation across choice alternatives in discrete choice models: an application to modeling residential location choice behavior. Journal of Transport Geography, 19(2), str. 294-303.

DOI: $10.1016 /$ j.jtrangeo.2010.03.013

Srinivasan, S. (2005): Influence of residential location on travel behavior of women in Chennai, India. V: National Research Council (ur.): Research on women's issues in transportation, report of a conference. Volume 2, technical papers, str. 4-13. Washington, DC, TRB.

Tran, M. T., Zhang, J., Chikaraishi, M., in Fujiwara, A. (2016): A joint analysis of residential location, work location and commuting mode choices in Hanoi, Vietnam. Journal of Transport Geography, 54, str. 181-193. DOI: 10.1016/j.jtrangeo.2016.06.003

van Acker, V., Mokhtarian, P. L., in Witlox, F. (2014): Car availability explained by the structural relationships between lifestyles, residential location, and underlying residential and travel attitudes. Transport Policy, 35, str. 88-99. DOI: 10.1016/j.tranpol.2014.05.006

Van der Vlist, Arno J., Gorter, C., Nijkamp, P., in Rietveld, P. (2002): Residential mobility and local housing-market differences. Environment and Planning A, 34(7), str. 1147-1164. DOI: 10.1068/a34176

Vega, A., in Reynolds-Feighan, A. (2009): A methodological framework for the study of residential location and travel-to-work mode choice under central and suburban employment destination patterns. Transportation Research Part A: Policy and Practice, 43(4), str. 401-419. DOI: 10.1016/j.tra.2008.11.011

Vos, J. de, in Witlox, F. (2016): Do people live in urban neighbourhoods because they do not like to travel? Analysing an alternative residential self-selection hypothesis. Travel Behaviour and Society, 4, str. 29-39. DOI: 10.1016/j.tbs.2015.12.002

Waddell, P., Bhat, C., Eluru, N., Wang, L., in Pendyala, R. M. (2007): Modeling interdependence in household residence and workplace choices. Transportation Research Record: Journal of the Transportation Research Board, 2003(1), str. 84-92. DOI: 10.3141/2003-11

Wang, L., Waddell, P., in Outwater, M. L. (2011): Incremental integration of land use and activity-based travel modeling, Transportation Research Record: Journal of the Transportation Research Board, 2255(1), str. 1-10. DOI: 10.3141/2255-01
Wang, M., Yang, Y., Jin, S., Gu, L., in Zhang, H. (2016): Social and cultural factors that influence residential location choice of urban senior citizens in China - The case of Chengdu city. Habitat International, 53, str. 55-65. DOI: 10.1016/j.habitatint.2015.10.011

Wang, Y., Peng, Z., in Chen, Q. (2018): The choice of residential layout in urban China: A comparison of transportation and land use in Changsha (China) and Leeds (UK). Habitat International, 75, str. 50-58. DOI: 10.1016/j.habitatint.2018.04.005

Wu, W., Zhang, W., in Dong, G. (2013): Determinant of residential location choice in a transitional housing market: Evidence based on micro survey from Beijing. Habitat International, 39, str. 16-24. DOI: 10.1016/j.habitatint.2012.10.008

Yang, L., Zheng, G., in Zhu, X. (2013): Cross-nested logit model for the joint choice of residential location, travel mode, and departure time. Habitat International, 38, str. 157-166. DOI: 10.1016/j.habitatint.2012.06.002

Yi, C., in Lee, S. (2014): An empirical analysis of the characteristics of residential location choice in the rapidly changing Korean housing market. Cities, 39, str. 156-163. DOI: 10.1016/j.cities.2014.03.002

Yu, B., Zhang, J., in Li, X. (2017): Dynamic life course analysis on residential location choice. Transportation Research Part A: Policy and Practice, 104, str. 281-292. DOI: 10.1016/j.tra.2017.01.009

Zhang, J., Yu, B., in Chikaraishi, M. (2014): Interdependences between household residential and car ownership behavior: A life history analysis. Journal of Transport Geography, 34, str. 165-174. DOI: 10.1016/j. jtrangeo.2013.12.008

Zhuge, C., Shao, C., Gao, J., Dong, C., in Zhang, H. (2016): Agent-based joint model of residential location choice and real estate price for land use and transport model. Computers, Environment and Urban Systems, 57, str. 93-105. DOI: 10.1016/j.compenvurbsys.2016.02.001

Zondag, B., in Pieters, M. (2005): Influence of accessibility on residential location choice. Transportation Research Record: Journal of the Transportation Research Board, 1902, str. 63-70. DOI: 10.3141/1902-08 